\title{
PENERAPAN METODE PROMETHE DALAM SISTEM PENDUKUNG KEPUTUSAN PENDISTRIBUSIAN TEPUNG TAPIOKA
}

\author{
Eka Yulia Sari ${ }^{*}$, Matsudir ${ }^{2^{*}}$, Yusuf Hendra Prataam ${ }^{3 *}$, Kusrini 4 \\ 1,2,3)Magister Teknik Informatika Universitas Amikom Yogyakarta \\ Jl. Ringroad Utara Condong Catur Depok Sleman, 55281, Indonesia \\ 4)Dosen Universitas Amikom Yogyakarta \\ Jl. Ringroad Utara Condong Catur Depok Sleman, 55281, Indonesia \\ Email: ekasari2107@gmail.com,matsudir@gmail.com,yusufhp92@gmail.com, \\ kusrini@amikom.ac.id
}

\begin{abstract}
UD Matsu Jaya mandiri merupakan usaha dagang yang bergerak dalam bidang produksi tepung tapioka. Tepung tapioka didistribusikan ke berbagai wilayah yang potensial. Setiap tahunnya, UD Matsu Jaya Mandiri mempunyai target penjualan, sehingga penentuan wilayah pendistribusian yang tepat akan mempengaruhi target penjualan, namun hal tersebut masih menjadi kendala bagi pengambil keputusan pada UD Matsu Jaya MAndiri. Untuk itu perlu adanya sistem pendukung keputusan untuk mendukung pengambilan keputusan dalam pemilihan pendistribusian tepung tapioka agar lebih tepat. Penelitian ini menerapkan metode promethee untuk mengembangkan sistem pendukung keputusan pendistribusian tepung tapioka pada UD Matsu Jaya Mandiri. Data penelitian bersumber dari UD Matsu Jaya Mandiri terkait penjualan pada tahun 2017. Alternatif yang digunakan adalah Surabaya (A1), Semarang (A2), Yogyakarta (A3) dan Jakarta (A4). Penelitian ini menggunakan 5 kriteria yaitu Harga, Ongkos Kirim, Jumlah Permintaan, Jumlah Suplier dan Pangsa pasar. Hasil yang diperolah yaitu sistem dapat membantu pengabil keputusan pada UD Matsu Jaya Mandiri dalam pendistribusian tepung tapioka dan perubahan bobot dan tipe preferensi akan mempengaruhi hasil perangkingan. Sistem pendukun keputusuan ini dapat membantu pihak UD Matsu Jaya Mandiri dalam mengambil keputusan dalam pemilihan pendistribusian tepung tapioka.
\end{abstract}

Keyword : Promethee, Sistem Pendukung Keputusan, Pendistribusian 


\section{PENDAHULUAN}

UD. Matsu Jaya Mandiri adalah salah satu usaha dagang yang bergerak dalam bidang produksi tepung tapioka. UD Matsu Jaya Mandiri mendistribusikan hasil produksinya dengan memasarkan ke berbagai wilayah yang potensial dan memiliki target penjualan tiap tahunnya, namun dalam menentukan wilayah pendistribusian yang tepat menjadi kendala yang akan mempengaruhi jumlah dalam pendistribusian dan penjualan. Kegiatan pendistribusian sangat penting bagi perusahaan yang bertujuan dalam memperluas area pemasaran produk barang dan jasa kepada konsumen secara tepat dan sesuai kebutuhan konsumen tersebut (Amertha dkk 2017). Dalam menentukan pasokan barang dalam bidang usaha merupakan keputusan yang penting, penentuan lokasi distribusi yang tepat dapat meningkatkan keunggulan kompetitif serta menciptakan rantai pemasokan barang yang optimal. Keuntungan yan didapatkan adalah salah satunya adalah posisi perusahaan yang sangat kuat dalam persaingan pengadaan barang sesuai permintaan pasar.

Berkembangnya teknologi yang begitu cepat, menyebabkan pemilik usaha dapat menyelaraskan teknologi pada proses bisnisnya. Teknologi membantu berbagai tugas dan pekerjaan, sehingga mempercepat dan memudahkan dalam hal pengambilan keputusan dalam perusahaan. Pemanfaatan system pendukung keputusan pada UD. Matsu Jaya Mandiri dapat membantu permasalahan dalam menentukan lokasi pendistribusian tepung tapioka.

Metode PROMETHEE adalah peringkatan yang cukup sederhana dalam konsep dan aplikasi dibandingkan dengan metode lain untuk analisis multi kriteria (Navarro dkk 2016). Metode promethee mempunyai kelebihan dalam pemeringkatan alternatif menggunakan fungsi preferensi dan bobot yang berbeda-beda yang digunakan oleh sistem pemeringkatan berdasarkan preferensi dan bobot dari kriteria-kriteria tertentu (Fikri dkk 2016).

Sebagai pendukung untuk penelitian ini, terdapat beberapa penelitian terdahulu yang relevan. Penelitian yang dilakukan oleh Rizal Setiansyah, Titik Lusiani yang berjudul Sistem Pendukung Keputusan untuk Menentukan Prioritas Perbaikan Sarana dan Prasarana Pengairan Menggunakan Metode PROMETHEE menyebutkan Dalam suatu urutan rangking usulan perbaikan yang dihasilkan pada metode PROMETHEE memungkinkan setiap nomor rangking terdapat lebih dari satu 
usulan perbaikan. Hal ini disebabkan usulan perbaikan memiliki nilai yang sama serta berguna dalam menghemat banyak waktu untuk penentuan prioritas perbaikan sarana dan prasarana pengairan (Fadlin dkk 2017).

Penelitian yang berjudul Analisis Hasil Prediksi Dengan Metode PROMETHEE menghasilkan Aplikasi yang telah di ujikan dengan 150 data siswa-siswi rekomendasi penerima beasiswa, memiliki tingkat kesuaian dengan teknik manual sebesar $85 \%$ data terpilih secara otomatis. Hasil perhitungan ini dengan Aplikasi munkin terjadi sedikit perbedaan dibelakang koma (biasanya digit ke 3 atau 4 setelah koma dikarenakan pada aplikasi perhitungan tidak mengalami pembulatan, sedangkan pada perhitungan manual ini telah melewati beberapa kali pembulatan(Mesran dkk 2017).

Pada penelitian yang berjudul Pemilihan Supplier Bahan Baku Partikel Dengan Metode AHP dan PROMETHEE menyebutkan kriteria-kriteria yang digunakan CV. Mitra Jaya dalam pemilihan supplier bahan baku partikel ukuran $122 \mathrm{~cm}$ x $244 \mathrm{~cm} \mathrm{x} 9 \mathrm{~mm}$ adalah quality dengan bobot kriteria sebesar 0.19 , delivery dengan bobot kriteria sebesar 0.17 , performance history dengan bobot kriteria sebesar 0.06 , price dengan bobot kriteria sebesar 0.36 , communication system dengan bobot kriteria sebesar 0.06 , operating control dengan bobot kriteria sebesar 0.05, attitudes supplier dengan bobot kriteria sebesar 0.04 dan geographical location dengan bobot kriteria sebesar 0.08. Hasil urutan ranking supplier didapatkan bahwa UD. TL sebagai peringkat pertama dengan nilai net flow sebesar 0.254, UD. SD sebagai peringkat kedua dengan nilai net flow sebesar 0.144 dan PT.KTI sebagai peringkat ketiga dengan nilai net flow sebesar -0.397(Mochammad dkk 2016) [9].

\section{METODE}

Metode penelitian yang dilakukan dalam penelitian ini meliputi identifikasi masalah, analisis kebutuhan data, perancangan sistem dan pengujian. Alur dari metode penelitian dapat dilihat pada Gambar 1.

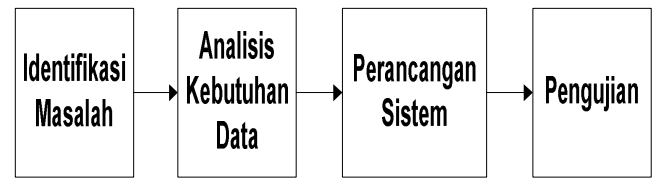

Gambar 1. Alur Penelitian

1. Identifikasi Masalah

Pada tahap identifikasi masalah dilakukan pencarian masalah apa yang 
akan diangkat untuk topik penelitian ini, pada penelitian ini UD. Matsu Jaya Mandiri dalam rangka memperluas area pendistribusian produk tapioka membutuhkan sistem pendukung keputusan dalam menentukan wiliayah mana yang akan dilakukan pendistribusian secara tepat dan menghasilkan keuntungan bagi UD. Matsu Jaya Mandiri

\section{Analisis Kebutuhan Data}

Tahap ini adalah menentukan data yang digunakan dalam melakukan penelitian ini, dalam hal penelitian ini akan menggunakan metode PROMETHEE. Berikut tahapan yang dilakukan dalam metode PROMETHEE (Vijay dkk 2010):

a. Menentukan Kriteria, Bobot dan Alternatif

b. Menentukan Tipe Preferensi Parameter Berikut tipe preferensi dalam metode PROMETHEE :

\section{a. Kriteria biasa (Usual Criterian)}

Pada preferansi ini tidak ada beda antara a dan $\mathrm{b}$ jika dan hanya jika $\mathrm{f}(\mathrm{a})$ $=\mathrm{f}(\mathrm{b})$, apabila nilai kriteria pada masing-masing alternatif memiliki niai berbeda, pembuat keputusan membuat preferensi mutlak untuk alternatif yang memiliki nilai yang lebih baik. Rumus perhitungannya terlihat pada persamaan 1 berikut ini :

$H(d)=\left\{\begin{array}{l}0 \text { Jika, } d \leq 0 \\ 1 \text { Jika, } d>q\end{array}\right.$

\section{b. Kriteria quasi (Quasi Criterian)}

Dua alternatif memiliki preferensi yang sama penting selama selisih atau nilai $\mathrm{H}(\mathrm{d})$ dari masing-masing alternatif untuk kriteria tertentu tidak melebihi nilai q, dan apabila selisih hasil evaluasi untuk masingmasing alternatif melibihi nilai $\mathrm{q}$ maka terjadi bentuk preferensi mutlak. Jika pembuat keputusan menggunakan criteria kuasi,maka harus menentukan nilai $\mathrm{q}$, dimana nilai ini dapat menjelaskan pengaruh yang signifikan dari suatu kriteria. Rumus perhitungannya terlihat pada persamaan 2 berikut ini :

$$
H(d)=\left\{\begin{array}{l}
\text { 0Jika, } d \leq q \\
1 \text { Jika, } d>q
\end{array}\right.
$$

\section{c. Kriteria Preferensi Linier}

Dalam kriteria preferensi linier dapat dilihat sebuah kejelasan bahawa selama nilai selisih memiliki nilai yang rendah dari $p$, preferensi dari pembuat keputusan terjadi peningkatan secara linier dengan nilai d, jika nilai d lebih besar bila dibandingkan dengan nilai $\mathrm{p}$, maka terjadi preferensi mutlak. Pada saat 
pembuat

keputusan

mengidentifikasikan

beberapa

kriteria untuk tipe ini, harus ditentukan nilai dari kecenderungan atas (nilai p). Rumus perhitungannya dapat dilihat pada persamaan 3 berikut ini:

$$
H(d)=\left\{\begin{array}{c}
0 j i k a, d \leq 0 \\
\frac{d}{q} j i k a, 0 \leq d \leq p \\
1 j i k a, d>p
\end{array}\right.
$$

\section{d. Kriteria Level (level criterian)}

Didalam kondisi seperti ini, kecenderungan tidak berbeda $\mathrm{q}$ dan kecenderungan preferensi $\mathrm{p}$ adalah ditentukan secara simultan. Jika d berada diantara nilai $\mathrm{q}$ dan $\mathrm{p}$, hal ini berarti situasi preferensi yang lemah $(\mathrm{H}(\mathrm{d} 0=0,5)$. Rumus perhitungannya dapat dilihat pada persamaan 4 berikut ini :

$$
H(d)=\left\{\begin{array}{c}
0 j i k a, d \leq q \\
\frac{1}{2} \text { jika, } 0 \leq d \leq p \\
1 \text { jika, } d>p
\end{array}\right.
$$

e. Kriteria Preferensi Linier dan Area yang Tidak Berbeda Pengambil keputusan mempertimbangkan peningkatan preferensi secara linier tidak berbeda hingga preferensi mutlak dalam area antara dua kecenderungan $\mathrm{q}$ dan $\mathrm{p}$. Rumus perhitungannya dapat dilihat pada persamaan 5 berikut ini :

$$
H(d)=\left\{\begin{array}{c}
0 j i k a, d \leq q \\
\frac{d-q}{p-q} j i k a, q<d \leq p \\
1 j i k a, d>p
\end{array}\right.
$$

c. Menghitung Menghitung nilai indeks preferensi multikriteria

Indeks preferensi multikriteria ditentukan berdasarkan rata-rata bobot dari fungsi preferensi Pi. Seperti pada persamaan 7 berikut ini :

$$
\varphi(a, b)=\sum_{i=1}^{n} \pi_{i} P_{i}(a, b): \forall a, b \in A
$$

Dimana $\varphi(a, b)$ merupakan intensitas preferensi pembuat keputusan yang menyatakan bahwa alternatif a lebih baik dari alternatif $b$ dengan perimbangan secara simultan dari seluruh kriteria.

d. Menghitung Leaving Flow dan Entering Flow

Digunakan untuk menentukan urutan prioritas pada proses PROMOTHEE yang menggunakan urutan parsial. Untuk mengitung leaving flow dapat menggunakan persamaan 8 dan menghitung entering flow menggunakan persamaan 9 berikut ini :

$$
\varphi^{+}(a)=\frac{1}{n-1} \sum x \in A \varphi(a, x)
$$

$$
\varphi^{-}(a)=\frac{1}{n-1} \sum x \in A \varphi(a, x)
$$

\section{e. Menghitung Net Flow}

Net flow digunakan untuk menghasilkan keputusan akhir penentuan urutan dalam menyelesaikan masalah sehingga menghasilkan urutan lengkap dengan 
perhitungan menggunakan persamaan 10 berikut ini :

$\varphi(a)=\varphi^{+}(a)-\varphi^{-}(a)$

3. Perancangan Sistem

Pada penelitian ini, sistem pendukung keputusan dibuat dengan bahasa pemrograman WEB. Berikut perancangan DFD pada gambar 2 dan Perancangan database pada gambar 3 yang dilakukan dalam penelitian ini :

a. Perancangan DFD

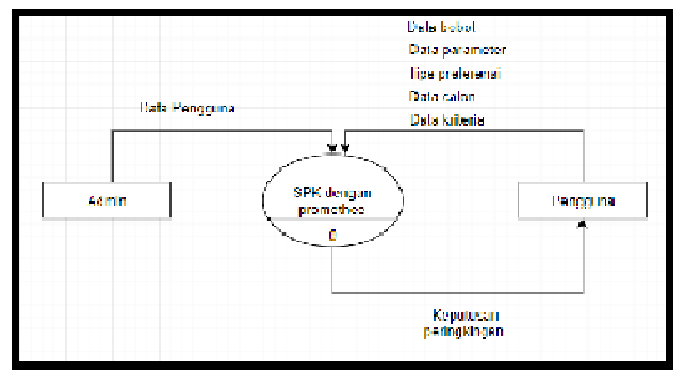

Gambar 2. Perancangan Diagram Konteks

b. Perancangan Database

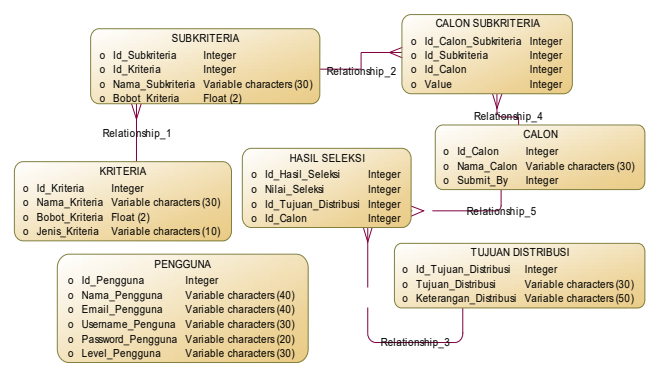

Gambar 3. Perancangan Database

c. Alur Sistem

4. Pengujian

Pengujian dalam penelitian ini menggunakan 3 macam pengujian yaitu :

a. Pengujian skenario aplikasi yaitu melakukan uji terhadap aplikasi itu 
sendiri apakah fungsi dalam aplikasi sudah berjalan sesuai dengan yang diinginkan.

b. Pengujian perbandingan hasil perhitungan manual dengan hasil dari aplikasi apakah sudah sesuai hasilnya.

c. Pengujian terhadap pengguna terhadap aplikasi tersebut apakah aplikasi mudah dipahami oleh pengguna baik data yang akan dimasukkan ataupun hasil yang ditampilkan.

\section{HASIL DAN PEMBAHASAN}

Langkah awal, dibutuhkan kriteria-kriteria dan bobot untuk melakukan proses perhitungan sehingga akan didapatkan alternatif pendistribusian terbaik. Nantinya alternatif yang tertinggi akan dipilih dan akan diusulkan kedalam sistem pendukung keputusan pendistribusian tepung tapioka.

\section{Implementasi Metode PROMETHEE}

Pada metode PROMETHEE, diperlukan kriteria-kriteria yang akan menjadi bahan perhitungan pada proses perangkingan dalam pemilihan pendistribusian tepung tapioka. Kriteria, alternatif, tipe preferensi dan parameter $\mathrm{q}$ dan $\mathrm{p}$ yang digunakan dapat dilihat pada tabel 1 berikut ini:

Tabel 1. Kriteria,Atenatif, Tipe Preferensi dan Parameter Q dan P

\begin{tabular}{|c|c|c|c|c|c|}
\hline \multirow{2}{*}{$\begin{array}{c}\text { Alterna } \\
\text { if }\end{array}$} & \multicolumn{5}{|c|}{ Kriteria } \\
\hline & K1 & $\mathrm{K} 2$ & K3 & K4 & K5 \\
\hline A1 & 11500 & 1900 & 20 & 7 & 8 \\
\hline A2 & 10000 & 1200 & 15 & 6 & 10 \\
\hline A3 & 10500 & 1500 & 5 & 3 & 40 \\
\hline A4 & 11000 & 2000 & 2 & 2 & 20 \\
\hline $\begin{array}{l}\operatorname{Min} / \\
\operatorname{Max}\end{array}$ & Max & Min & Max & Min & Max \\
\hline Bobot & 0,2 & 0,2 & 0,2 & 0,2 & 0,2 \\
\hline $\begin{array}{l}\text { Tipe } \\
\text { Prefere } \\
\text { nsi }\end{array}$ & V & III & IV & II & III \\
\hline $\begin{array}{l}\text { Parame } \\
\text { ter q }\end{array}$ & 100 & 100 & 1 & 1 & 2 \\
\hline $\begin{array}{l}\text { Parame } \\
\text { ter } \mathrm{p}\end{array}$ & 1000 & 300 & 10 & 2 & 10 \\
\hline
\end{tabular}

Keterangan :

$$
\begin{array}{ll}
\mathrm{K}_{1} & =\text { Kriteria Harga } \\
\mathrm{K}_{2} & =\text { Ongkos Kirim } \\
\mathrm{K}_{3} & =\text { Jumlah Permintaan } \\
\mathrm{K}_{4} & =\text { Jumlah Suplier } \\
\mathrm{K}_{5} & =\text { Pangsa Pasar }
\end{array}
$$



$\mathrm{A}_{1}=$ Sura
$\mathrm{A}_{2} \quad=$ Semarang
$\mathrm{A}_{3} \quad=$ Yogyakarta
$\mathrm{A}_{4} \quad=$ Jakarta

Tabel 2. Indeks Preferensi Multikriteria

\begin{tabular}{|l|r|l|l|l|r|}
\hline Alternatif & A1 & A2 & A3 & A4 & Jumlah \\
\hline A1 & 0 & - & 0 & 0,889 & 0,1 \\
\hline A2 & 0,61 & 0 & 1,189 & 1,8 & 3,6 \\
\hline A3 & $-2,2$ & $-3,01$ & 0 & $-1,41$ & $-6,622$ \\
\hline A4 & 0,71 & $-1,8$ & $-0,41$ & 0 & $-2,922$ \\
& 1 & & & & \\
\hline Jumlah & $-2,3$ & $-5,6$ & 0,78 & 1,278 & - \\
\hline
\end{tabular}

Tabel 3. Hasil Penyelesan

\begin{tabular}{|c|c|c|c|c|}
\hline $\begin{array}{c}\text { Leavin } \\
\text { g FLow }\end{array}$ & $\begin{array}{c}\text { Enterin } \\
\text { g Flow }\end{array}$ & $\begin{array}{c}\text { Net } \\
\text { Flow }\end{array}$ & Rangk & Ket \\
\hline 0,0333 & $-0,767$ & 0,8 & 2 & Distribusi \\
\hline 1,2 & $-1,867$ & 3,067 & 1 & Distribusi \\
\hline$-2,207$ & 0,259 & $-2,467$ & 4 & $\begin{array}{c}\text { Tidak } \\
\text { Layak }\end{array}$ \\
\hline$-0,974$ & 0,425 & $-1,4$ & 3 & $\begin{array}{c}\text { Tidak } \\
\text { Layak }\end{array}$ \\
\hline
\end{tabular}

Langkah pertama, tentukan kriteria,alternatif tipe preferensi dan parameter $\mathrm{q}$ dan $\mathrm{p}$ seperti pada tabel
1.Selanjutnya hitung selisih antar alternatif yang akan digunakan untuk perhitungan indeks preferensinya. Langkah selajutnya hitung indeks preferesi multikrteria denga persamaan 7 . Setelah didapatkan indeks preferensi multikriteria hitung leaving flow, enterin flow serta net flow dengan persamaan 8,9 dan 10. Dari hasil netflow dapat kita lakukan perangkingan dari yag paling besar kepaling rendah. Dari hasil perhitungan pada tabel 16 diatas dapat disumpulkan alternatif yang sangat layak diusulkan ke dalam Sistem pendukung keputusan pendistribusian tepung tapioka yang sesuai dengan interval $>0$, maka dari itu wilayah yang tepat diusulkan adalah Surabaya dan Semarang.

2. Pengujian Skenario Aplikasi

Pada pengujian aplikasi digunakan pengujian blackbox testing untuk menguji semua fungsi-fungsi yang ada pada aplikasi sistem pendukung keputusan pendistribusian tepung tapioka. Kuisioner diberikan kepada pemilik UD Matsu Jaya Mandiri. Hasil dari blackbox testing ini ditampilkan pada tabel 4 berikut ini: 
Tabel 4. Pengujian Skenario Aplikasi

\begin{tabular}{|c|c|c|c|}
\hline $\begin{array}{l}\text { Fung } \\
\text { si }\end{array}$ & Output Seharusnya & Kesuaian & Ket \\
\hline \multirow{2}{*}{$\begin{array}{l}\text { Form } \\
\text { Kriter } \\
\text { ia }\end{array}$} & $\begin{array}{l}\text { 2. Sistem merubah } \\
\text { kriteria, bobot dan } \\
\text { subkriteria sesuai } \\
\text { yang di edit }\end{array}$ & Sesuai & $\begin{array}{c}\text { sudah } \\
\text { dapat } \\
\text { digunakan }\end{array}$ \\
\hline & $\begin{array}{l}\text { 3. Sistem menyimpan } \\
\text { data kriteria, bobot } \\
\text { dan subkriteria }\end{array}$ & Sesuai & $\begin{array}{c}\text { sudah } \\
\text { dapat } \\
\text { digunakan }\end{array}$ \\
\hline \multirow{3}{*}{$\begin{array}{l}\text { Form } \\
\text { Alter } \\
\text { natif }\end{array}$} & $\begin{array}{l}\text { 1. Sistem menambah } \\
\text { alternatif yang di } \\
\text { inputkan }\end{array}$ & Sesuai & $\begin{array}{c}\text { sudah } \\
\text { dapat } \\
\text { digunakan }\end{array}$ \\
\hline & $\begin{array}{l}\text { 2. Sistem merubah } \\
\text { alternatif sesuai yang } \\
\text { di edit }\end{array}$ & Sesuai & $\begin{array}{c}\text { sudah } \\
\text { dapat } \\
\text { digunakan }\end{array}$ \\
\hline & $\begin{array}{l}\text { 3. Sistem menyimpan } \\
\text { data alternatif }\end{array}$ & Sesuai & $\begin{array}{c}\text { sudah } \\
\text { dapat } \\
\text { digunakan }\end{array}$ \\
\hline \multirow[t]{2}{*}{$\begin{array}{l}\text { Form } \\
\text { Hasil }\end{array}$} & $\begin{array}{l}\text { 1.Sistem dapat } \\
\text { menginputkan tipe } \\
\text { preferensi } \\
\text { berdasarkan pilihan } \\
\text { yang ada }\end{array}$ & Sesuai & $\begin{array}{c}\text { sudah } \\
\text { dapat } \\
\text { digunakan }\end{array}$ \\
\hline & $\begin{array}{l}\text { 2. Sistem dapat } \\
\text { memberikan nilai } \mathrm{p} \\
\text { dan } \mathrm{q}\end{array}$ & Sesuai & $\begin{array}{c}\text { sudah } \\
\text { dapat } \\
\text { digunakan }\end{array}$ \\
\hline
\end{tabular}

\section{Pengujian Perbandingan Hasil}

Perhitungan Manual dengan Aplikasi

\section{a. Percobaan Dengan Perhitungan}

Manual

Pada proses pengujian manual, akan dilakukan perhitungan manual yang akan dibandingkan dengan hasil aplikasi. Hasil yang diperoleh dapat dilihat pada tabel 3. Untuk hasil

\begin{tabular}{|c|c|c|c|}
\hline Fungsi & $\begin{array}{l}\text { Output } \\
\text { Seharusnya }\end{array}$ & $\begin{array}{c}\text { Kesuai } \\
\text { an }\end{array}$ & Ket \\
\hline $\begin{array}{l}\text { Form } \\
\text { Hasil }\end{array}$ & $\begin{array}{l}\text { 2. Menampilkan } \\
\text { hasil leaving } \\
\text { flow, entering } \\
\text { flow dan net } \\
\text { flow }\end{array}$ & Sesuai & $\begin{array}{c}\text { sudah } \\
\text { dapat } \\
\text { digunaka } \\
\text { n }\end{array}$ \\
\hline $\begin{array}{l}\text { Form } \\
\text { Kriteria }\end{array}$ & $\begin{array}{l}\text { 1. Sistem } \\
\text { menambah } \\
\text { kriteria dan } \\
\text { bobot yang di } \\
\text { inputkan }\end{array}$ & Sesuai & $\begin{array}{c}\text { sudah } \\
\text { dapat } \\
\text { digunaka } \\
\text { n }\end{array}$ \\
\hline
\end{tabular}

perhitungan pada sistem dapat dilihat pada gambar 6 dibawah ini :

Gambar 6 Screenshoot Hasil Perhitungan Pada Sistem

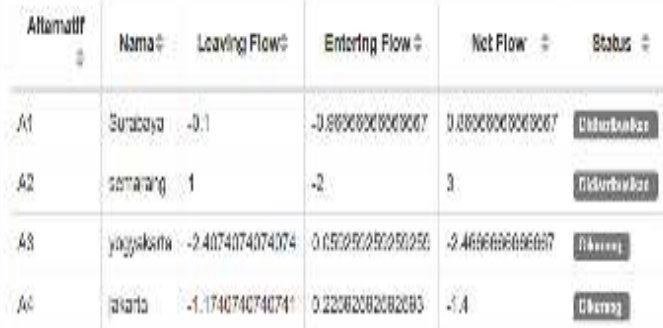

Dari hasil perhitungan perhitungan pada sistem dengan perhitungan manual sudah sama, yang dapat dilihat dari perhitungan hasil manual pada tabel 3 dengan Gambar 6. Untuk itu, sistem sudah jalan sesuai algoritma Promethee yang digunakan pada penelitian ini.

4. Pengujian dengan perubahan tipe preferensi dan bobot

Pada proses pengujian, pada penelitian ini juga akan menggunakan pengujian 


\begin{tabular}{|c|c|c|c|c|}
\hline $\begin{array}{l}\text { Alt } \\
\text { ern } \\
\text { atif }\end{array}$ & $\begin{array}{c}\text { Leavi } \\
\text { ng } \\
\text { Flow }\end{array}$ & $\begin{array}{c}\text { Enter } \\
\text { ing } \\
\text { Flow }\end{array}$ & $\begin{array}{c}\text { Net } \\
\text { Flow }\end{array}$ & $\begin{array}{c}\text { Ketera } \\
\text { ngan }\end{array}$ \\
\hline A1 & 0,25 & $\begin{array}{c}0,58 \\
3\end{array}$ & $-0,33$ & $\begin{array}{r}\text { Tidak } \\
\text { Layak }\end{array}$ \\
\hline A2 & 0,759 & $\begin{array}{c}- \\
0,16 \\
7\end{array}$ & 0,925 & $\begin{array}{c}\text { Distrib } \\
\text { usi }\end{array}$ \\
\hline A3 & 0,380 & 0,35 & $\begin{array}{c}0,027 \\
8\end{array}$ & $\begin{array}{c}\text { Distrib } \\
\text { usi }\end{array}$ \\
\hline A4 & $\begin{array}{c}0,028 \\
8\end{array}$ & $\begin{array}{c}0,64 \\
9\end{array}$ & $\begin{array}{c}- \\
0,520 \\
3\end{array}$ & $\begin{array}{r}\text { Tidak } \\
\text { Layak }\end{array}$ \\
\hline
\end{tabular}

dengan perubahan bobot dan perubahan

\begin{tabular}{|c|c|c|c|}
\hline & Tipe & \multicolumn{2}{|c|}{ Parameter } \\
\cline { 3 - 4 } Kriteria & Preferen & & \\
si & $\mathrm{q}$ & $\mathrm{p}$ \\
\hline Harga & 1 & 100 & 0 \\
\hline ongkos kirim & 1 & 100 & 300 \\
\hline $\begin{array}{c}\text { jumlah } \\
\text { permintaan }\end{array}$ & 1 & 1 & 10 \\
\hline jumlah & & & \\
supplier & 1 & 1 & 2 \\
\hline pangsa pasar & 1 & 2 & 10 \\
\hline
\end{tabular}

tipe Preferensi untuk mengetahui pengaruh perubahan bobot serta perubuhan pengaruh Tipe preferensi. Percobaan pertama dilakukan dengan perubahan tipe preferensi dengan menggunakan seluruhnya tipe Biasa yaitu bisa dilihat pada tabel 5. Hasil dari percobaan pertama dapat dilihat pada Tabel 6 dibawah ini:
Tabel 5. Percobaan Pertama

Tabel 6. Hasil Percobaan Pertama

Pada percobaann kedua, digunakan perubahan bobot antar masing-masing kriteria yang dapat dilihat pada tabel 7 berikut ini :

Tabel 7. Percobaan Kedua

\begin{tabular}{|c|c|c|c|c|}
\hline \multirow{2}{*}{ Kriteria } & \multirow[b]{2}{*}{ Bobot } & \multirow{2}{*}{$\begin{array}{c}\text { Tipe } \\
\text { Prefere } \\
\text { nsi }\end{array}$} & \multicolumn{2}{|c|}{ Parameter } \\
\hline & & & q & $\mathrm{p}$ \\
\hline K1 & 0,22 & 5 & 100 & 1000 \\
\hline K2 & 0,22 & 3 & 100 & 300 \\
\hline K3 & 0,27 & 4 & 1 & 10 \\
\hline K4 & 0,139 & 2 & 1 & 2 \\
\hline K5 & 0,25 & 3 & 2 & 10 \\
\hline
\end{tabular}

Dari hasil percobaan satu dan dua, diperoleh kesimpulan bahwa perubahan bobot dan perubahan tipe preferensi akan mempengaruhi hasil keluaran keputusan oleh sistem. Hasil percobaan kedua terdapat pada tabel 8 .

Tabel 8. Hasil Percobaan Kedua 
5. Pengujian Validasi

Pengujian validasi dilakukan untuk memastikann uji kelayakan sistem. Dimana pengujian ini membandingkan hasil keluaran sistem dengan hasil aktual. Pengujian ini dilakukan pada tombol simpan, hapus, lihat dan tambah. Berikut adalah hasil pengujian validasi dapat dilihat dari tabel 9.

Tabel 9 Hasil Pengujian Validasi

\begin{tabular}{|l|l|l|}
\hline Tombol & Hasil Sistem & $\begin{array}{l}\text { Nila } \\
\text { Simpan }\end{array}$ \\
$\begin{array}{l}\text { Dapat Menyimpan } \\
\text { sesuai dengan yang } \\
\text { diinputkan user }\end{array}$ & 100 \\
\hline Hapus & $\begin{array}{l}\text { Dapat menghapus } \\
\text { data sesuai dengan } \\
\text { keinginan user }\end{array}$ & 100 \\
\hline Lihat & $\begin{array}{l}\text { Dapat menampilkan } \\
\text { data sesuai dengan } \\
\text { keinginan user dan } \\
\text { user memahami isi } \\
\text { data yang di } \\
\text { tampilkan }\end{array}$ & \\
\hline Tambah & $\begin{array}{l}\text { Form penambahan } \\
\text { data berfungsi dengan } \\
\text { baik sesuai dengan } \\
\text { keinginan user dan } \\
\text { user }\end{array}$ & \\
\hline
\end{tabular}

Dari tabel 9,didapatkan hasil pengujian validasi yaitu :

Hasil pengujian validasi :

\begin{tabular}{|l|c|c|c|c|}
\hline $\begin{array}{c}\text { Alt } \\
\text { ern } \\
\text { atif }\end{array}$ & $\begin{array}{c}\text { Leavi } \\
\text { ng } \\
\text { Flow }\end{array}$ & $\begin{array}{c}\text { Enter } \\
\text { ing } \\
\text { Flow }\end{array}$ & $\begin{array}{c}\text { Net } \\
\text { Flow }\end{array}$ & $\begin{array}{c}\text { Ketera } \\
\text { ngan }\end{array}$ \\
\hline A1 & 0,067 & 0,73 & $-0,67$ & $\begin{array}{c}\text { Tidak } \\
\text { Layak }\end{array}$ \\
\hline A2 & 0,53 & 0,27 & 0,27 & $\begin{array}{c}\text { Distrib } \\
\text { usi }\end{array}$ \\
\hline A3 & 0,53 & 0,27 & 0,27 & $\begin{array}{c}\text { Distrib } \\
\text { usi }\end{array}$ \\
\hline A4 & 0,47 & 0,33 & 0,13 & $\begin{array}{c}\text { Distrib } \\
\text { usi }\end{array}$ \\
$=$ & $100+100+90+100$ & $* 100 \%=97,5 \%$
\end{tabular}

6. Pengujian User Acceptance Test (UAT)

Pengujian ini dilakukan pada sisi tampilan dan kepuasan end-user terhadap sistem.Pada pengujian ini dilakukan dengan memberikan kuisioner kepada 10 responden. Berikut adalah hasil dari beberapa 10 kuisioner yang sudah diisikan oleh responden dapat dilihat pada tabel 10

Tabel 10. Hasil Percobaan User Acceptence Test (UAT) 


\begin{tabular}{|r|r|r|r|r|r|r|}
\hline 6 & $\begin{array}{l}\text { Tampilan } \\
\text { sistem mudah } \\
\text { dikenali }\end{array}$ & 2 & 4 & 4 & - & - \\
\hline 7 & $\begin{array}{l}\text { Kemudahan } \\
\text { mencari menu } \\
\text { dan tombol }\end{array}$ & 1 & 3 & 2 & 2 & 2 \\
\hline Total Nilai & 11 & 34 & 20 & 3 & 2 \\
\hline
\end{tabular}

Dari hasil pada tabel 10 menunjukan bahwa prosentase tertinggi sebesar $48,5 \%$ setuju. Berasarkan data hasil kuisoner diatas, dapat dicari prosetase masingmasing pernyataan dengan persamaan 11 sebagai berikut :

$y=\frac{P x 100}{Q x R}$

Keterangan :

$\mathrm{P} \quad=$ Banyak jawaban responden tiap variabel

Q = Jumlah Responden

$\mathrm{R} \quad=$ Banyak Soal

$\mathrm{Y}=$ Nilai Prosentase

\section{KESIMPULAN}

Dari penelitian ini maka diperoleh kesimpulan sebagai berikut :

1. Sistem pendukung keputusan pendistribusian tepung tapioka

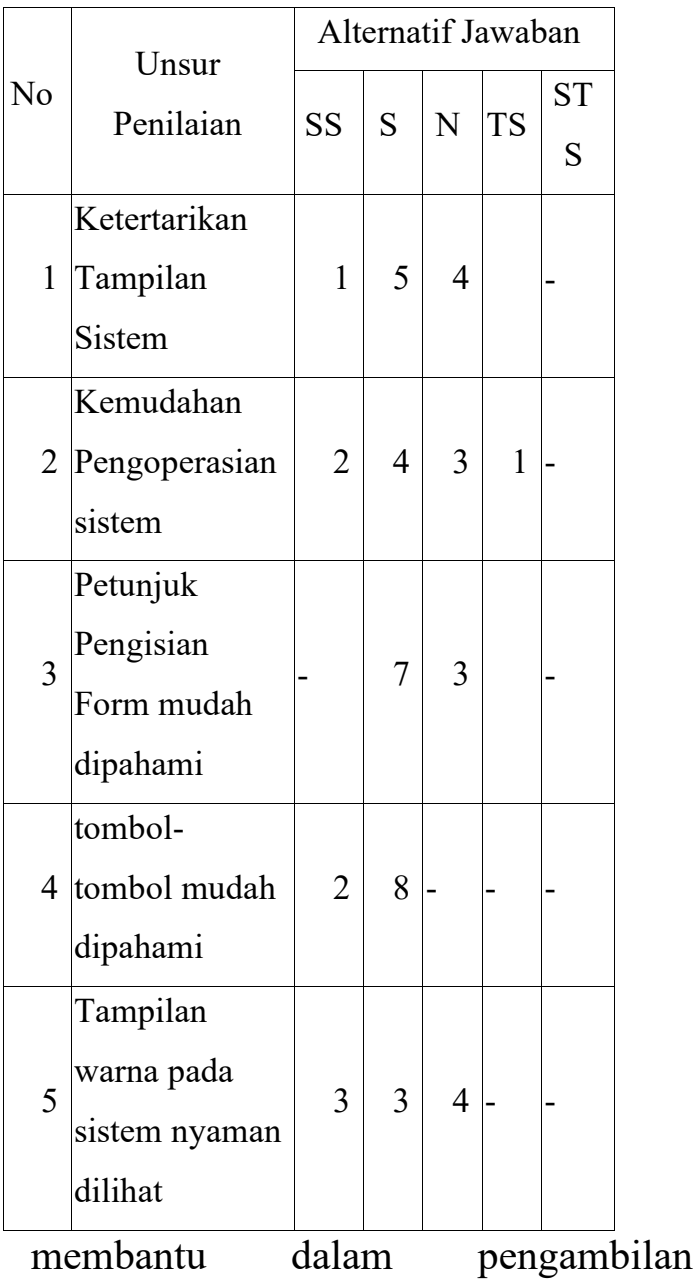

keputusan pemilihan pendistribusian tepung tapioka pada UD Matsu Jaya Mandiri.

2. Keluaran dari sistem pendukung keputusan pendistribusian tepung tapioka dalam penelitian ini berupa perangkingan dan hasil perangkingan berupa "TIDAK LAYAK" dan "DISTRIBUSI. Keterangan tersebut berdasarkan hasil net flow, apabila hasil net flow $>0$ maka keterangannya “DISTRIBUSI" sedangkan apabila hasil net flow $<0$ maka keterangan yang didapat yaitu " TIDAK LAYAK" 
3. Dari hasil pengujian dan perocbaan, dapat ditarik kesimpulan yaitu perubahan bobot dan perubahan tipe preferensi akan mempengaruhi hasil perangkingan yang didapat.

4. Hasil Akurasi pengujian validasi sebesar 97,5\% dan User Acceptence User sebesar $48,5 \%$ setuju.

\section{DAFTAR PUSTAKA}

Arnetha,S,Raintung.,Centhya, $\mathrm{S}$, Bambulu., 2017, Sistem Pendukung Keputusan Pemilihan Lokasi Distribusi Produk Triplex di PT. Duta Cakrawala Mandiri dengan Metode Simple Additive Weighting (SAW), Jurnal ELECTRICALAND, Vol 5, No 1 Hal-4.

Ayu,A,Sembiring., Abdul,S, S.,Saidi, R, Siregar., 2018, Sistem Pendukung Keputusan Penentuan Prioritas Pengembangan Industri Kecil Menengah di Kabupaten Karo Menggunakan Metode Topsis, Majalah Ilmiah INTI, Vol 13, No 2, Hal 199-204.

Bintang,C,S., Garuda, G., Kristian,S., 2018, Sistem Pendukung Keputusan Pemilihan Ambassador PT Matahari Department Store dengan Metode Promethee II,
Majalah Ilmiah INTI, Vol 13, No 2, Hal 205-2010.

Kusrini, Konsep dan Aplikasi Sistem Pendukung Keputusan.:ANDI, 2007.

H,Navarro-Hellín., J, Martínez-delRincon., R, DomingoMiguel.,F,Soto-Valles., R, TorresSánchez., 2016, A decision support system for managing irrigation in agriculture,Computers and Electronics in Agriculture, Vol 124, Fikri,D.,Sameer,K.,Sharfudding, A, K., Vipul, J., 2016, Designing an Integrated AHP Based Decision Support System For Supplier Selection in Automotive Industry, Expert Systems With Application, Vol. 62.

Fadlin., Lince,T,S., Abdul, K., Mesran, Andysah, P,U,Siahaan., 2017, Best Student Selection Using Extended Promethee II Method, International Journal of Recent Trends in Engineering \& Reseacrh, Vol 3 Issue 08, Hal 21-29.

Mesran., Garuda,G., Suginam., Robbi, R., 2017, Implementation of Elimination and Choice Expressing Reality (ELECTRE) Method in Selecting the Best Lecturer ( Case Study STMIK BUDI DARMA), 
International Journal of

Engineering Research \&

Technology (IJERT), Vol 6, Issue 02, Hal 141-144.

Mochammad, I, P., Wirda, F., Nova, M., Andysah,P,U, Siahaan., 2016, Tuition Reduction Determination Using Fuzzy Tsukamoto, International Journal of Engineering Science Invention, $\mathrm{Vol}$ 5, Issue 9, Hal 68-72.

Vijay., M,A., Shanker,C., 2010, Facility Location Slection Using Promethee II Method, Proceedings of the 2010 International Conference on Industrial Engineering and Operations Management Dhaka, Bangladesh, January 9 - 10, 2010.

Hadi, S., 2016, Decision Support System to Majoring High School Student Using SAW Method, Jurnal Ilmiah SISFOTENIKA, Vol 6 No 2, Hal 147- 157.

Marlince., 2018., Aplikasi Penentuan Karyawan Terbaik Metode AHP dan Metode Promethee, JUSIKOM PRIMA(Jurnal Sistem Informasi Ilmu Komputer Prima), Vol 1 No 2, Hal 68-71

A,B Maulachela., S,Hidayat., N, Fitriani., A, A, Rizal., J, Budiarto., A,S,Anas., G,S,Nugraha., A,
Juliansyah., J,Qudsi., Abdurahim., M,Yunus., N,K,Sriwinarti., 2018, Promethee: As a Supporting Decision of Selection of Poor Rice Receivers., IOP Conf. Series : Journal of Physics, 2019.

Mesran.,Imam, S., Melinda,A., 2017, Penerapan Metode PROMETHEE II pada Sistem Layanan dan Rujukan Terpadu (SLRT), KOMIKA(Konferensi Nasional Teknologi Informatika dan Komputer), Vol 1, No 1, Hal 276285

Petrus, M., Wida, S., 2011, Defining Relative Qualities Of Object Oriented Design Implementations Using AHP and PROMETHEE, Proceedings of the International Symposium on the Analytic Hierarchy Process,2011.

Tia, I., Agus, P, W., 2017, Sistem Pendukung Keputusan dalam Merekomendasikan Unit Terbaik di PDAM Tirta Lihou Menggunakan Metode Promethee, Jurnal Teknologi dan Sistem Informasi, Vol 5 No 1, Hal 159-165.

Lee,A,S., 2007,Action Is an Artifact : What Action Research and Design Science Offer to Each Other, Springer, Laredo, Texas, USA 
D.Nofriansyah, S. Kom, M. Kom, And S.

T. Dharma, "Modul : Sistem

Pendukung Keputusan,” 2016. 